\title{
A signal witness? Hamilton meets Grundtvig (1849-50)
}

\author{
By S. A. J. Bradley
}

In 1849-50, Andrew Hamilton, a Scot from Stirling, spent sixteen months in Denmark with the aim of observing Danish life and culture. His aim was facilitated by letters of introduction to substantial figures in Copenhagen through whom he went on to gain access to various other notable houses and circles. Eminent among his hosts were Professor Niels Laurits Høyen, Bishop J. P. Mynster, the Dowager Queen Caroline Amalie, H. C. Andersen, Baron Henrik Stampe of Nysø - and N. F. S. Grundtvig. Søren Kierkegaard he did not pluck up sufficient resolve to accost. A sample of his reminiscences of these meetings provides some measure of his judgment and his usefulness as a contemporary witness, as does the fact of his election to membership of the prestigious Kongelige Nordiske Oldskriftselskab. Though biographical facts about him are sparse, and though he (naturally) knows nothing of Grundtvig or Grundtvigianism after 1852 , his reminiscences were written down almost immediately and thus his book (published 1852) may be thought to have a certain limited priority over the better known memoirs of Edmund Gosse, published in 1911.

In 1849, the professors of Rostock University "seemed to look on Copenhagen as a far off, barbaric, Scandinavian chief-town." Rostock, near the Baltic coast of north Germany, had once been a favoured place for young Danes to go to study, but "any former intercourse betwixt Denmark and Rostock has (...) left no traces at the present day. I met no Scandinavians in the once distinguished, though now, alas! decayed university."

Thus wrote Andrew Hamilton, a Scot from Stirling, in his twovolume book Sixteen Months in the Danish Isles (I, Preface, 1-2). Nobody in Rostock had ever been nearer Copenhagen than he then was: it was a terra incognita.

The wars in the Duchies had given a finishing stroke to the feeling of estrangement, or rather had added a feeling of enmity to the people's minds that was not called for. There was, for the [p. 3] time, a decided dislike of Denmark on the part of the North Germans. I found afterwards it was reciprocated (I, Preface, 2-3).

The times were turbulent. In the previous year, outbreaks of popular revolution had led to repressive measures by the authorities in the German states as in France and Italy. In Denmark, also in 1848, the Marts-Revolution (March revolution) had (albeit peacefully) hastened 
King Frederik VII's historic renunciation of royal absolutism in favour of constitutional democracy, and by 1849 the status and role of institutions within State and Church were in the melting-pot as the terms of the new Danish Constitution were hammered out ahead of its inauguration in June that year. Over the same period, ancient disputes between Denmark and the Duchies of Holsten and Slesvig had flared up into war (1848-51). Nevertheless, despite the perilous circumstances of hostilities between the kingdom of Denmark and the Duchies backed by the German Confederation, following Denmark's termination of a truce in February 1849, Hamilton resolved to travel onwards into Denmark and Scandinavia. His account of the sixteenmonth stay is potentially useful both as an outsider's view upon Copenhagen society in the mid-nineteenth century and as a sample of the image of Denmark and Danish culture that was being communicated at that time to England and the English-speaking world.

Thus Hamilton set out on 27 March 1849. With him he carried letters of recommendation, introducing him to various substantial citizens of Copenhagen. Though the first letter was received with nearincomprehension by the addressee, leaving Hamilton to move on dejected to the next, he soon met with hospitality and settled down for a stay which eventually extended to sixteen months. One of his hosts in Copenhagen was Professor Niels Laurits Høyen (1798-1870), art historian and critic. It was in Høyen's company, as they strolled one evening around the ramparts of Kastellet, that he met the poet Christian Winther. Hamilton could read Danish moderately well, he says, but:

In poetry it was not difficult for me to get beyond my depth. At that period I tried Grundtvig, but made nothing of him, which was not wonderful, for, long after, I found it called for a stretch of attention to master many of his productions, glorious as I could discern they must be. But some other bards were less difficult. I read some pieces of Oehlenschläger, as well as some of his prose, and dabbled a little with Heiberg and Winther ${ }^{1}$ (I, xii, 165).

He was pleased to have met Winther: "This was the first poet whose personal acquaintance I had the pleasure to make" (I, xii, 167); but it was not long before he "felt some desire to go farther" and arranged a meeting with Grundtvig himself (more will be said of this meeting below). Despite these earlier difficulties with Grundtvig's poetry, by the time he published his book in 1852 Hamilton felt confident in placing it in a Danish perspective:

Of a very different stamp from Oehlenschläger is Grundtvig, who, even during the life of the former, was by a certain party regarded as a far higher poet. Now, we may safely accord him the first place in his 
own country. I own, I might, under certain circumstances, myself have joined the Grundtvig party, but let us abjure all parties! There is, unquestionably, something marvellously spirit-moving about the man's utterances. But then Grundtvig's poetical utterances (and it is of poetry alone that I am now speaking) are, with the exception of his hymns, very few in number; they are like momentary ejaculations between years of silence. Or rather like one thunder-storm in a summer; for Grundtvig seldom speaks but he thunders.

"It would be a sin to say" that Grundtvig is the embodiment of the floating poetic spirit of present Denmark. One would, on the contrary, almost be disposed to look on him as a most magnificent anachronism. But neither would be correct. The truth is, he is a seer. He beholds things far away, behind, before, above; but it is almost unreasonable in him to expect his fellow-creatures with one consent to understand him.

Certainly Grundtvig can take upon him the spirit of the Old-North, although Oehlenschläger could not. There are some of his productions which might just as well, the language excepted, have been written or spoken, by one of Scandinavia's former skalds. And it is on this account that Grundtvig's admirers have fallen so foul of Oehlenschläger, forgetting that there can be good in more ways than one. I delight in both. I shocked the one party by saying that I admired in Grundtvig what I admired the absence of in Oehlenschläger, and the other party by admitting that Oehlenschläger had nothing of the Old Northern spirit, which however was the simple truth, and by no means to his discredit. ${ }^{2}$

The two veterans were on friendly terms, nearly throughout, I believe. I know they had abundant veneration for one another. In years, Grundtvig follows not far behind his now departed fellowSkald $^{3}$ (II, x, 212).

With apparent ease (which contrasts, one might think, with the difficulty Grundtvig had found in gaining access to London society back in 1829), Hamilton proceeded to make his way into the highest circles of Danish cultural life. On a tour of southern Sjælland he was invited to stay at Nysø, not far from Præstø, the manor-house of Baron Henrik Stampe, whose wife Christine had made their home a meetingplace for artists, writers, politicians and other leading figures in Danish society. ${ }^{4}$ In 1839 Christine Stampe had caused an atelier to be built in the gardens there for the internationally renowned sculptor Bertel Thorvaldsen and though Thorvaldsen had died in 1844 Hamilton was able to view various of his sculptures at Nysø. He devotes a chapter of his book to Thorvaldsen, and in the course of it tells the anecdote of Grundtvig's part in the atelier's dedication:

The day of the atelier's being taken possession of, was a festival day at the chateau. Some other guests were then under the roof; among the rest the poet-priest Grundtvig. The latter was earnestly begged to 
indite a song for the occasion, which, after much declining, he agreed to do. As I was informed, "He said he had no turn for writing occasional pieces, he had never done so, and was sure he would not succeed. But in the morning, he came down with a manuscript ode in his hand which he would read to us; we could see what we thought of it. He read it, and we all thought it the very thing, beautiful beyond all mending." The ode was recited, and Thorwaldsen took possession of his garden-studio (I, xxiii, 377). ${ }^{5}$

Thorvaldsen was one Danish artist whose work, in contradiction of the Rostock professors' scorn for "barbaric" Copenhagen, was by then known and esteemed among educated and refined people across Europe. Another was Hans Christian Andersen. In 1850, Hamilton was invited by Andersen to accompany him to the Casino theatre. The play being performed that evening was Andersen's own, Ole Lukøie. Eventyr-Comedie $i$ tre Acter (Ole Shut-eye [cp. the English nurseryrhyme figure, Willie Winkie]. Romantic Comedy in Three Acts): it had opened on 1 March 1850 and had met with great popular success. Hamilton sat by Andersen's side and "I had the benefit of his elucidations as the per[p. 231]formance went on" (II, xi, 230-31). He had no doubt read Mary Howitt's recently published translation (from the German edition) of Andersen's autobiography, The True Story of my Life (London, 1847); at any rate he was convinced of Andersen's genius and readily subscribed to the orthodoxy (perhaps reinforced by Andersen himself, along with other "elucidations") that in his own homeland Andersen had first been misunderstood and subsequently underappreciated:

In Denmark he is not done justice to, and although much read in England, I question whether he is done justice [p. 217] to here either. I look on him as a most original soul, one whom his country ought to cherish as among its rarest possessions. It is very tedious to hear the reactionary parrot-cry against him, simply because ignorant people at first prized him for qualities he had not, and not for those he had, and then discovering that the imagined elements were wanting, wisely concluded that he had no element of genius in him at all. I believe his fables will bear their novelty and originality with them down to the end of time (II, $x, 216-17)$.

In his diary entry on 3 July 1850 Andersen notes: "Brev fra Jette Wulff og Skotlænderen Hamilton" (Letter from Jette Wulff and the Scot Hamilton); and on 4 July "Skrevet til Jette Wulff med Anbefalings Breve for Hamilton" (Written to Jette Wulff with letters of recommendation for Hamilton) (Dagbøger, 3 (1845-50), 410). This person appears to be our Andrew Hamilton. The letters were addressed to various people in Sweden, evidently for use in Hamilton's eventual onward journey. ${ }^{6}$ 
Also opened to Hamilton was access to royal circles - or, at any rate, an audience with the generous-spirited, culturally-engaged and religiously devout Dowager Queen Caroline Amalie, patroness of (among others) Grundtvig:

It was also now that I had the honour of being presented to her Majesty the Queen Dowager Caroline Amalie. I was eager to see a Princess so distinguished for the virtues that can adorn her rank, (the earnest profession of Christianity marking and ennobling all the rest), as well as celebrated for that beauty of person which has so long been the pride of the land. Her Majesty has also claims on a Briton's tribute of respect, being so nearly related to the Royal Family of England. ${ }^{7}$ I was most graciously received. And it was, indeed, heart-moving to stand before a queen who had so beautifully realized the title of mother of the people, and who had also shown the possibility of a Queen walking humbly with her God. Her Majesty has all along chosen the better part that shall not be taken from her - even on a throne and in a careless court adorning in all things that doctrine she acknowledged - [p. 178] and in later and most painful times, I doubt not she has experienced the peace that passeth understanding ${ }^{8}$ (II, vii, 177-78).

One notable Copenhagener whom Hamilton frequently saw but could never brace himself to accost was Søren Kierkegaard:

There is a man whom it is impossible to omit in any account of Denmark, but whose place it might be more difficult to fix; I mean Søren Kierkegaard. Kierkegaard's habits of life are singular enough to lend a (perhaps false) interest to his proceedings. He goes into no company and sees nobody in his own house, which answers all the ends of an invisible dwelling; I could never learn that any one had been inside of it. Yet his one great study is human nature; no one knows more people than he. The fact is he walks about town all day, and generally in some person's company; only in the evening does he write and read. When walking, he is very communicative, and at the same time manages to draw everything out of his companion that is likely to be profitable to himself. I saw him almost daily in the streets, and when he was alone I often felt much inclined to accost him, but never put it into execution. I was told his "talk" was very fine. Could I have enjoyed it, without the feeling that I was my self being mercilessly pumped and sifted, I should have liked to very much (II, xvi, 270).

Hamilton - who asserts that "I could read many Danish books with ease" (I, xii, 168) - read and thought well of Kierkegaard's Sygdommen til Døden which was published (1849) not long after his arrival in Copenhagen.

Among the notable personages to whose counsels Hamilton did actively seek and gain admittance, one of the most influential was J. P. 
Mynster who had been kongelig confessionarius (chaplain royal) since 1828 and Bishop of Sjælland since 1834. To him - "To His Excellency The Right Reverend J. P. Mynster, D.D. [Doctor of Divinity], Lord Bishop of Copenhagen" - Hamilton dedicated his book. ${ }^{10}$

On the Copenhagen clergy in general, Hamilton passed cautious judgment which, it may be assumed, was influenced by views which Mynster had expressed to him:

The Metropolis is not ill-provided with faithful preachers. In this there has taken place a change since the beginning of the present century. Formerly, there was a universal Rationalism; now, in the pulpits, there is a greater proportion of evangelical truth. I say "in the pulpits," because the change has principally been effected there. The movement towards Gospel-Orthodoxy commenced with, and went out from the clergy. This was, perhaps, so far well, and the right and natural order; but it has had the effect of placing the clergy on a point proportionally far in advance of the people, and the people too far in the rear of their clergy. At the same time, it is to be expected that in the course of years, the influence acting downwards will produce its blessed effects; already there has been in the present century a vast [p. 180] amount of fruit, and it is to be hoped that the impression will become more and more pervading.

There are still churches in the metropolis in which nothing but the driest and deadliest morality is preached in place of the Gospel; at the same time these are not more than two or three in number (II, viii, 179$80)$.

When Hamilton's book was published, the famous, half-reluctant yet scathing attack by Søren Kierkegaard upon the kind of Christianity represented by Mynster still lay a couple of years in the future ${ }^{11}$ but already Mynster had his high-principled adversaries. In particular, he and Grundtvig stood in a deeply embittered relationship with each other, and doubtless Hamilton heard much of the bishop's disapproval of Grundtvig's concept of the Church and their conflict over such issues as revision of the baptismal rite, compulsory baptism into the State Church, sognebaandsløsning (dissolution of parochial ties) and, more personally, over the bishop's refusal in 1838 to allow Grundtvig to confirm his own sons. Yet when Hamilton looks around the contemporary scene, he finds much to esteem in Grundtvig the pastor:

The place of worship in the metropolis best provided with godly and gifted men is the Palace Church [Slotskirken in Christiansborg]. This is a large, handsome, but ill-built place, not at all like a Christian temple. Its regular pastor is the Reverend Mr. Paulli, Court Chaplain, a very admirable and popular preacher. ${ }^{12} \mathrm{He}$, however, officiates only once a fortnight. On the alternate Sundays, the pulpit is filled by the Bishop of Copenhagen [i.e. Mynster] and Professor Martensen. ${ }^{13}$ 
The Palace Church is the most fashionable place of worship in Copenhagen; and it is thus a peculiarly happy circumstance that its preachers should be men of such influence and power. The large building is always full and usually crowded. The audience is the highest in rank and importance, many of whom, go, doubtless, for fashion's sake, whilst the rest of the church is filled by a more miscellaneous throng. In every way it is a matter of high moment that, just in this church, such splendid displays of the Christian Truth should be never-failing.

[p. 181] Other churches which can also be mentioned as supplied by a Gospel ministry are Holmen's Kirke and Trinitatis. They are always very full. So is the Garnison Kirke; all of which seems to betray on the part of the population a certain desire for good.

One other church, small in size, and mean in appearance, as well as remote in position, which, nevertheless, has in recent times borne a weighty part in the development of spiritual life in Copenhagen, must not be omitted in an enumeration of the evangelically-supplied churches. I mean the chapel of the Vartou Hospital. ${ }^{14}$ Grundtvig's position in Copenhagen is as Chaplain of this Hospital, for which cause he preaches every Sunday, nominally to the aged and infirm pensioners of the wards, but in reality to a numerous, though most select company of his own earnest admirers, those who, having received spiritual good by his means, are the constant and devoted attenders on his ministry, never dreaming of hearing any other preacher. All who have been converted under Grundtvig, have generally at the same time received an entirely peculiar direction in Christianity, which, although excellent in many ways, has the unhappy effect, among others, of causing them to separate themselves in the spiritual life, to a great extent, from their fellow-Christians in their country. At the same time, Grundtvig's influence on the spiritual life of his native land is as great as if there were the completest communion between him, or rather his [p. 182] followers, and the outer world. In fact, strangers, both of town and country, drop continually into the Vartou Church, and doubtless carry away deep impressions. But, setting aside such passing influences, and the stronger influence that Grundtvig exercises by means of other clergymen who, moulded by his hands, preach the faith in much the same style in different places, after all, the best and highest use of the Vartou Church in the metropolis of Denmark is in these years as a signal witness against the want of faith in the nominal church. It would certainly not be a desirable consummation if all faithful people were to take the same direction, for, earnest and genuine as the Grundtvig party is, and valuable as its strong grasp of the faith is (as a witness), still the tendency of the school is in the form of faith to hide the Gospel. Grundtvig has done much to crush and quell unbelief, and he and his immediate friends are full of the spirit of Christianity, and it is on this account that this peculiar development of Christian truth and life is valuable. But there is a purer Christianity and a more excellent 
way; and blessed be God! Denmark does not want now for manifestations of the purest Gospel!

While rejoicing, however, in the churches to which I alluded above as places where Christianity in its freeness and simplicity is made known, I cannot but highly prize the ministrations of the Vartou Church, were it for no other reason than [p. 183] that they have acted as so powerful an antidote and so restless an awakening force. Otherwise, to any one it ought to be a treat to hear a sermon there (II, viii, 180-83).

Hamilton's meeting with Grundtvig himself was arranged through their mutual friend, Professor Høyen, who had earlier introduced Hamilton to Christian Winther:

I got the same friend to call with me on Grundtvig, the hero of Denmark for the time being, the reviver of heroic thoughts, and prophet of the church and true skald of the north. Not that Grundtvig is esteemed as the greatest poet of the age in Denmark, except by a small circle of his devoted admirers, - that honour seems by almost universal suffrage to be awarded to Oehlenschläger, - but he is the true representative of Scandinavian song, notwithstanding the fact of Oehlenschläger's having written many pieces on Scandinavian subjects, - but more of this in its fitting place. Neither is Grundtvig the greatest divine in Denmark; but had he no other praise, he has, at least, that of versatility. As a divine, he stands at the head of a powerful party in the Danish church, the high orthodox; of this form of [p. 168] Lutheranism, he has been the reviver, and is now the pillar: he plays a conspicuous part in the political movements of his native land, and, finally, is the great poet I have indicated. I hope to speak on these points with more minuteness afterwards.

My notions of the poet-priest were somewhat of the dimmest and most confused when first I came to speak with him face to face. I knew only of the weighty part he played in so many different realms; what that part was, in any of these realms, I knew most imperfectly. There is a difficulty which attends the motions of some men, so as fairly to nonplus any one who cannot judge for himself, but receives second-hand information from differently disposed onlookers; and I consider no one fit to receive first-hand impressions who must seek them by means of a foreign language. I had gazed at some of Grundtvig's writings, but, even though I could read many Danish books with ease, they had conveyed to my mind no clear conceptions. I had also gone, once or twice, to the Vartou church, and looked at the aged minister of God, and heard his feeble voice, without picking up the sense; I had seen that heavy, spirit-laden head, that stone-like brow, with its thin, cold [p. 169] covering of straggling grey hair, and those ocean deep eyes, where the midsummer night-sun and midwinter moon of a Scandinavian heaven seemed to be reflected. ${ }^{15}$ But, farther than the evidence of the existence of a genius, it was not possible for 
me then to behold anything distinctly. And, all the more so, that genius never exists without some misrepresenting medium, through which you are almost sure to have the earliest glances of it. There are ever some unblest detractors, who manage to convey a false idea of the man of genius, before it is possible for you, by contact and personal experience, to form a fair estimate of him. And it is, $\mathrm{Oh}$ ! for a glimpse, once in time, of some naked great spirit, without any derogatory preconception whatsoever!

Among the incidentals peculiar to Grundtvig, I had comfortably been made aware of his general liking to Englishmen and aught that was English; and this was some fortification against the meeting with a man who, it was evident, at the merest glance, might be stern towards what he did not like. I met with a gentle reception, and departed with a more specific impression. To me he had not talked much that day, probably because I was too subdued to be very conversable, [p. 170] but he had said sundry memorable words, and I had heard his conversation with his gifted and more congenial friend, my introducer [i.e. Høyen]. One Sunday, soon after, in coming out of Vartou Church, I encountered the aged pastor and enjoyed a walk home with him to his own house. ${ }^{16}$ The clergymen of Copenhagen go to church and return from it in their gown and ruff, a practice I find desirable, as it shows a certain confidence in the goodness of what they are going to do, a proclamation, in the hearing of a whole population, that God's worship either is to be or has just been performed.

The sacrament of the Lord's Supper had been dispensed that day in church. I asked whether it took place every Sunday. Grundtvig said he wished it to be every Sunday, but there were not always communicants. He took occasion from that to remark on the little stress that was laid upon the sacraments in the Calvinistic churches, true enough when compared with the Lutheran. In his own church the Lord's Supper is always dispensed if any intending communicants have given in their names the day before; a privilege of which I subsequently took advantage. I believe, in most other churches, there are particular days set apart, or a certain number of [p. 171] communicants necessary. The sacrament is administered according to the Lutheran method, the elements being consecrated wafer and wine. The officiating clergyman wears, above his usual black gown, a white surplice, and, over that, a scarlet velvet cope, with a large crucifix, embroidered in gold, on the back; - garments startling, at first, to Calvinistic eyes ${ }^{17}$ (I, xii, 165-71).

In Volume 2 of his book, Hamilton returns to Grundtvig and offers his English readership an assessment of Grundtvig's historic role in the Danish Church. The account of Grundtvig's views and the judgments passed upon them may be thought to show the influence of Mynster upon Hamilton. 
Grundtvig, also [as well, that is, as the eminent bishop, J. P. Mynster], has been a remarkable agent during the present century. He commenced about the year 1810. At that period, Rationalism was as yet little shaken, and he set about it with might and main to attack it. He had previously occupied himself solely with poetry; when the Faith laid hold of him, and it seemed to him a sin that he should be taken up with mythology, while the pastors of God's flock were neglecting their duty. So he stepped for[p. 265]ward as polemic, asserting the faith against all human might and reason. He was too loud for the times, and got into difficulties from the enmity of the Rationalistic party. In fact, for many years he was not a pastor of the National Church at all.

But these matters which, after all, have not directly to do with the revival of religion in this century, I must omit, as it is far too extensive a subject. Besides, Grundtvig's position, his controversy with Clausen, and other things, have been repeatedly put in print in England, which makes it the less needful for me to do so. ${ }^{18}$

Grundtvig has always had, and retains to this day, extraordinary powers as a preacher. He is what one would call stirring. In fact, this quality of stirringness (the rattling and shaking through of everything) is characteristic of him altogether. His sermons, even now when his voice has become very feeble, are sometimes extremely exciting. He has remarkable views of truth.

Besides the power which his preaching has had in commending certain parts of truths to men's minds and in making men think, the great influence which Grundtvig has exerted has been as a controversialist. He has from first to last fought against Rationalism in every form. Doubtless this was also a very important vocation in such times, and we must bear it in mind when looking at Grundtvig as a theologian. He has gone into extremes which he could scarcely have done had he not been obliged to oppose the reverse [p. 266] in others. He entertains many views which evangelically-minded men must regard as having a tendency towards error, and some which we would altogether pronounce false. For instance, his extraordinary ideas of the forms connected with baptism as necessary to the valid administering of that rite, the "seven questions," \&c., as if aught more could be necessary than the form our Lord laid down, "in the name of the Father, and of the Son, and of the Holy Ghost." The questions and profession of faith may be very good and excellent, but certainly they are not necessary. His views about the "living word," the allimportance of preaching, and many others, bear also the stamp of exaggeration.

Grundtvig is eminently not critical, but traditional. This is also by way of opposing the Rationalists. There is much worth investigating in the tendency of his views, but this book is evidently not the place for it, and perhaps I have already said too much. He has been a very valuable man as an opponent and destroyer of unbelief, but he has not succeeded so well in building up. There is too much of the Son of Thunder in him for the latter purpose; indeed he has often knocked 
down theories of his own very soon after he had raised them. And, in fact, he has too many theories about the church, missions, reading of the Bible, \&c., He does not himself put the Bible into the hands of an unconverted person, because there is no hope such a person can understand it. It was written for the church, and must be [p. 267] expounded orally by a believer, because faith cometh by hearing, \&c. Hence he does not think the Spirit of God doth instruct in the reading of the Word. ${ }^{19}$

Grundtvig's great idea is that of "The Faith once delivered to the Saints." To preserve this in its purity is his grand aim. His errors must be forgiven on account of the useful work he has done. There is something very splendid about the man's power. And I must again comment upon his hymns as those of this century, which raise its rank to that when Kingo and Brorson sang. ${ }^{20}$ Many of Grundtvig's hymns are the finest in the language; others, again, are in bad taste.

Dr Mynster's grand idea I should call, "The Gospel, the power of God unto salvation." I have said Grundtvig's was "The Faith once delivered to the Saints." I think from these two sentences, in some measure, a fair idea may be had of the difference between the two men. And it will be perceived how much more fitted for all times and eras the former is, how much more universal it is; while the latter is for an era, a limited time, a time of controversy (II, xvi, 264-67).

So much then for Grundtvig and poetry, Grundtvig and mythology and Grundtvig and the Church. Of Grundtvig and education Hamilton has little to say, directly. Chresten Kold's school at Ryslinge, supported by the Grundtvigians, did not open until the year after Hamilton left Copenhagen, and Christian Flor's school at Rødding in Slesvig, though established since 1844, had not as yet gained the preeminence in Denmark it was later to enjoy after its removal to Askov. However, Hamilton gives vent to a singularly blunt criticism of the contemporary Danish examination-culture which would so evidently have rejoiced the heart of Grundtvig that one cannot help wondering whether it does in fact echo - occasionally even word for word - some tirade delivered by Grundtvig to his Scottish visitor: ${ }^{21}$

Danish university education is heavily burdened with examinations. Altogether, a man destined for a learned profession in Denmark has a course of examinations to go through which, one would think, must leave him pretty thoroughly known and understood by his examiners. The process of sifting passes all precedent. Until you are thirty years old, or mayhap, for aught I know, till you are fifty, you are not safe - if you wish to make any change in your way of life - from being summoned before a board of examiners, and overhauled from stem to stern, being questioned about everything under heaven. In early life, every step is attended by an examination. Leaving school, entering college (or "becoming student" as the Danes express it), leaving college, whether for ever or only for the session, choosing a 
profession, studying for one, trying to enter upon it, \&c., in the university and out of the university before other examining powers, all is preceded or followed [p. 239] by a complete searching with regard to one's knowledge of what has been, is, and shall be.

The great number of wearisome lectures young men are forced to hear, and write down, year after year; and the extraordinary number of examinations for which they must study very hard - for they are not child's play - naturally deaden the spirit. Hence one may not wonder at the great monotony of character among professional men in Denmark after a certain time of life, and their curious idea of knowledge, as a goddess to be worshipped, doubtless, but one of the unloveliest divinities ever set up - a dry, dead, senseless thing. Better not think of knowledge as a goddess at all, but let her retain her vital spark: and better, I think, not to have so many examina and tentamina at the time youth should be rejoicing itself in the bright careless life which God has given it, taking all the good at His hand, and neither asking nor answering questions.

Here let me remark, I have met many individuals in Denmark, who formed delightful exceptions to the above rule of monotony, but they were only exceptions. And I thought, how strong their spirits must be to have sailed clear through all this ocean of upcast mire and dirt, and now to be passing over the bright expanse of life with their heaven-given rigging in wonderful keeping (II, xii, 238-9).

The usefulness of such a witness as Hamilton must of course to some considerable extent depend upon his credentials. It is therefore regrettable that I have not yet been successful in tracing any extensive biographical information about him.

One very remarkable biographical fact, however, is Hamilton's election to the Kongelige Nordiske Oldskriftselskab - apparently in 1849 or 1850 , during his stay in Denmark. Among the members of the Society (whose Protector at the time, His Majesty King Frederik VII, would preside over annual general meetings at Christiansborg Palace) were kings, princes, archbishops, archdukes and other nobility and dignitaries, as well as eminent Danes and other Scandinavians in the world of the arts and sciences. Among foreign nationals admitted were such as Thomas Tobin of Ballincollig near Cork, Ireland, industrialist, philanthropist and antiquary, who was subsequently elected fellow of the Society of Antiquaries of London (1853) and member of the Royal Irish Academy (1869); A. D. Wackerbarth, listed as Professor of Oscott College, Birmingham (the prestigious Roman Catholic college then recently associated with the dramatic reception of John Henry Newman into the Roman Catholic Church in 1845, two years after Grundtvig, with Caroline Amalie's backing, had gone to England in 
the vain hope of helping avert such an event), who was also a member of the Royal Astronomical Society and author of a notable metrical translation of the Anglo-Saxon poem Beowulf (1849); Henry Norton Shaw, Secretary of the Royal Geographical Society in London; and John Earle, Professor of Anglo-Saxon in the University of Oxford (the last two having been elected after Hamilton, in 1852). It was, then, very distinguished company indeed into which Hamilton was admitted.

The distinction certainly looked impressive when cited on the titlepage of his book - "Member of the Royal Society of Antiquaries of the North, at Copenhagen" - and may have helped to ensure that his book was (favourably enough) reviewed in at least two leading journals: in The Gentleman's Magazine, N. S. Vol. 38 (1852), 73-74, by Emily Taylor; and in the Athenaeum (June 5, 1852), 621-22, by Chorley. Such distinction, however, does not seem to have been accorded him in the reciprocal societies in Britain. He was not a Fellow of the Society of Antiquaries of London, nor a member of the Society of Antiquaries of Scotland; nor have I been able to find evidence of other publications under his name. I have seen nothing to suggest that he was related - at any rate, closely enough to be aware of it - to the Hamiltons of Sweden. There are, however, avenues of enquiry still to be explored which may yield further information.

As regards the integrity and reliability of Hamilton's reports, we have his own frank statement (I, Preface) that they were written largely from memory - but from a memory he confidently regarded as "tenacious and correct":

During the time that I spent in Denmark, I had no thought of writing a detail of my experiences there. Hence, no preparations were made by me - no materials collected. A year after quitting Denmark, and some time after my return to England, the idea occurred to me.

Although I profess to keep a Day-book, it has always been far too seldom written in to be of much use in a matter of this sort. My letters were not all extant.

The letters and Day-book were chiefly useful in reminding me of what had happened in connection with other things.

This book, then, is a series of recollections; it has been written from memory. I have been surprised to find my memory so tenacious and correct. Doubtless, much has escaped it; but nothing is stated which is not true.

Hamilton's book preceded by more than half a century the publication of the (now) much better known account of Edmund Gosse - Two Visits to Denmark 1872, 1874 (1911) - in which Gosse relied upon a 
characterisation of Grundtvig first formed almost forty years previously and therefore much advantaged by hindsight. In this light, Hamilton's witness - for all its uncertainties and notwithstanding its limited perspectives - is nevertheless of some considerable value among authentically contemporary accounts of Grundtvig.

\section{Acknowledgements}

For assistance in the researching of this article I am particularly grateful to George Pattison, Lady Margaret Professor of Divinity in the University of Oxford; Birgitte Langkilde, Librarian in the State and University Library in Aarhus; Bernard Nurse, Librarian of the Society of Antiquaries of London; and Iain G. Browne, Principal Curator, Manuscripts Division, National Library of Scotland.

\section{Bibliography}

Hamilton, Andrew (1852), Sixteen Months in the Danish Isles (2 vols), London.

Tudvad, Peter (2004), Kierkegaards København, Copenhagen 2004.

Notes

1 Adam Oehlenschläger (1779-1850), leading poet of Romanticism in Denmark, dramatist, laurel-crowned in Lund 1829 as 'king' of northern poets, died during Hamilton's stay in Denmark, on 20 January 1850. Johan Ludvig Heiberg (1791-1860) was long established as a poet, dramatist and professor by the time of Hamilton's visit, and had just been appointed (1849) as a Direktør of the Royal Theatre, Copenhagen. Christian Winther (1796-1876) had emerged as a published poet with his collection Digte (1828) though publication of his major work Hjortens Flugt still lay in the future (1855).

2 Hamilton's judgement here is curiously at odds with that of Grundtvig himself who had said (in lectures given in 1838 though not published - as Mands Minde [Within living memory] - until 1877; my translation): "In my eyes Oehlenschläger, from the moment I saw his Poetiske Skrifter [Poetic writings; vols. I-II, 1805], was a bard to whose shoulder I could hardly reach and whose wreath I did not covet at all - but the ancient North which he, in Vavlunder [i.e. Vaulundurs Saga, Weland's saga; in Poetiske Skrifter] and the Nordiske Digte [Nordic poems; 1807] had visited upon the wings of an eagle and surveyed with the eye of a falcon, this, I felt, was my poetic home: a long-slumbering warrior-strain from the pagan past had, under the loud din of battle and the song of the skald, awakened in me, and meant to be heard without accommodating or 
correcting itself to any of all those valid or invalid rules of art that had been framed upon the writings of the ancient Greeks and Romans."

3 This may qualify as the earliest recorded English usage of the term 'skald' applied to a post-medieval poet. According to the Oxford English Dictionary, the English form of the originally Icelandic word appears to have been introduced as 'scald' by Bishop Percy in his Five Pieces of Runic Poetry in 1763. The form 'skald' seems to have come into use fairly soon afterwards, in 1780 . These and all other $O E D$-cited examples, however, refer explicitly to the court poets of medieval Scandinavia. Thomas Warton, for example, whose three-volume History of English Poetry (1774-81) was much used by Grundtvig during preparation for his visits to England (1829-31), speaks (1775) of "many scalds from the north" involved in the viking settlement of Normandy. Sir Walter Scott, another English writer familiar to Grundtvig, mentions in Ivanhoe (1819) "the antique poetry of the Scalds." The Danish word skjald is extensively used by Grundtvig (as also by older poets such as Holberg, Wessel, Ewald and Oehlenschläger) of himself and of other post-medieval poets of the North, as a way of asserting that such latter-day poets stand in a direct line of inheritance from the ancient poets of the North. Has Hamilton adopted the word, in this contemporary application, from the example of Grundtvig? Has Grundtvig hereby indirectly contributed a usage to the English language? Incidentally, a number of words used by Hamilton appear to be newly coined analogues or anglicisations of Danish words. For example, he refers to Copenhagen as a 'Scandinavian chief-town' (Danish hovedstad) rather than 'capital (city)' and instead of the more familiar 'diary' he speaks of his 'Day-book' (Danish dagbog). In this practice, he calls to mind Grundtvig's friend George Stephens (1813-95), Professor in English at Copenhagen University 1855-93, who liked to name Copenhagen 'Cheaping-haven' and to coin new English words upon a Germanic etymological base in lieu of Latin-derived words. Grundtvig himself favoured similar linguistic strategies when he translated Saxo's Latin and Snorri's Icelandic into Danish. There appears to be a complex of philological cross-influences here which deserves exploration.

4 Hamilton does not actually name Nysø and refers to his host only as "Baron S---" but there can be no doubt as to identity and place.

5 The garden-studio is still to be seen at Nysø. The poem, Vølunds Verksted (Weland's workshop), was not in fact the first occasional piece Grundtvig had composed in Thorvaldsen's honour. To the celebrations of Thorvalden's return to Denmark in 1838 he had contributed the poem Ving-Thors Hammer.

6 Andersen's good connections in Sweden doubtlessly stemmed from his travels there the previous year (17 May to 15 August 1849). Denmark's military repulse of the German-backed insurgents from Slesvig-Holsten (and notably the battle of Fredericia, 6 July 1849) earned great admiration in Sweden, of which Andersen became the fortuitous recipient as a figure representative of his country. The finely-written account of his travels, $I$ 
Sverrig (In Sweden) was published in May 1851. This information was kindly supplied by my colleague Flemming Lundgreen-Nielsen.

7 Caroline Amalie (1796-1881) was daughter of Frederik Christian of Augustenborg and Louise Augusta (1771-1843) who was daughter of Caroline Mathilde (1751-75), wife of Christian VII of Denmark and sister to the British king George III, of the House of Hanover.

8 The "later and most painful times" upon which Caroline Amalie had fallen by 1852 when Hamilton published his book were doubtless those of the Three Years' War (1848-51) and its aftermath. Caroline Amalie's brothers, Christian August, Duke of Augustenborg in Slesvig, and Frederik, Prince of Nør in Slesvig, in pursuing certain claimed rights pertaining to their dynastic line against the King of Denmark and Duke of Slesvig-Holsten - namely their sister's husband, Christian VIII and then his successor, Frederik VII - contributed to the outbreak of (in effect) civil war between the kingdom and the duchies. In political as well as human terms it was an acutely painful position for Caroline Amalie. She remained loyal to the Danish cause against the Augustenborg dynasty and over time freed herself from Danish mistrust and won much popular esteem for her dedication to humanitarian and charitable activities and for her personal piety. I am grateful to Flemming Lundgreen-Nielsen for comment upon this point.

9 Peter Tudvad (Tudvad 2004, p. 356), noting this reference, comments (my translation): "It is tempting to see in Kierkegaard a Socrates - and in Hamilton to see a Nikias who in Plato's dialogue Laches maintains that everyone who enters into conversation with Socrates gets propelled around in the discussion and ends up having to give an account of the conduct of his own life." Tudvad presents no further biographical information on Hamilton.

10 Correctly speaking, Mynster was not Bishop of Copenhagen since the diocese of Copenhagen was not created until 1924; but at the Reformation the cathedra of the Bishop of Sjælland was moved from Roskilde to Copenhagen where the royal court also had its principal seat, and the Bishop of Sjælland achieved de facto primacy over the Danish ecclesiastical hierarchy.

11 Taking up words praising Mynster's Christian witness from a sermon by Mynster's successor, Bishop H. L. Martensen, Kierkegaard launched his sustained attack with an article in the newspaper Foedrelandet (18 December 1854), asking "Var Biskop Mynster et "Sandhedsvidne", et af "de rette Sandhedsvidner" - er dette Sandhed?" (Was Bp Mynster a "Witness to Truth", one of "the rightful Witnesses to Truth" - is this the truth?).

12 Just Henrik Voltelen Paulli, 1809-65, married to a daughter of Bishop J. P. Mynster.

13 Hans Lassen Martensen, 1808-84; subsequently Mynster's successor as Bishop of Sjælland, 1854-84.

14 The "small" and "mean" church was enlarged and reorganised just a few years later, in 1856 . 
15 The "aged" priest with his "feeble" voice was in fact to continue preaching regularly at Vartov for another twenty-two years, until his death in 1872 .

16 Grundtvig was then living in Vimmelskaftet, a few streets away from Vartov, towards the city centre.

17 Grundtvig's own splendidly embroidered messehagel (chasuble) which until recently hung in the vestry in Vartov Kirke is now undergoing conservation prior to being placed in the care of the Grundtvig Mindestuer at Udby.

18 Hamilton refers to the clash with Professor H. N. Clausen (1793-1877) whose book Catholicismens og Protestantismens Kirkeforfatning, Lare og Ritus (Constitution, doctrine and rites of Catholicism and Protestantism) immediately provoked Grundtvig to publish Kirkens Gienmoele (1825) in which he defended a certain (anti-Rationalist) view of the Church and accused Clausen of false teaching. Grundtvig was taken to court and adjudged to have defamed Clausen and violated censorship laws. He was fined and placed under lifelong censorship, though this sentence was lifted in 1838.

19 The archaic idiom ("doth instruct"), reminiscent of Bunyan and 17thcentury Quaker writings, suggests that Hamilton is alluding to a wellknown text, possibly to Isaiah 28:26.

20 Thomas Kingo (1634-1703), Danish bishop and hymnwriter, of Scottish ancestry, commissioned to produce a new hymnal (authorised 1699) popularly known through its long life as Kingos Salmebog (Kingo's Hymnal), whose hymns have given him a reputation, rivalled perhaps by Grundtvig alone, as Denmark's greatest hymnwriter. Hans Adolph Brorson (1694-1764), Danish bishop, hymnwriter and poet, who expressed remorse and sorrow for the world's sinful and transitory nature in hymns, and humility, gratitude and joy over the certainties of salvation, in affective poetry.

21 Hamilton's account of the examination culture then prevailing in Denmark may usefully be read alongside the article "Det Chinesiske Examens-Væsen" (The Chinese examination system) by Professor K. E. Bugge elsewhere in this number of Grundtvig-Studier (see page 91). 